\title{
Role of KVK in Strengthening of Livelihood Security of Self Help Group Tribal Farm Women in Palghar District, India
}

\author{
Vilas Jadhav* and J. Venkat Pirabu \\ Agril. Extension \& Rural Sociology Department of TNAU, Coimbatore, India \\ *Corresponding author
}

\begin{abstract}
A B S T R A C T
Krishi Vigyan Kendra, a planned scheme of Indian Council of Agricultural Research plays vital role by organizing various mandatory programmes to the women for their empowerment in respect of knowledge and adoption of technology for the augmentation of crop production, food security, livelihood security, etc. KVK emphasizes on women empowerment through formation and functioning of SHG and providing training on entrepreneurial training which helps them to develop self confidence, attitude, motivation, economic independence, decision making, leadership, social mobility, etc. Therefore, an attempt has made through this study to find out the role of KVK in strengthening livelihood security the SHG tribal farm women through their entrepreneurial activities. The present study was conducted in purposively selected Palghar district of Maharashtra state which is tribal dominated district. Total two blocks were selected, each block five villages were selected randomly where KVK has given training to the SHG tribal farm women. Thus, a total 10 villages were selected and from each selected villages 20respondents were selected. Thus, total 200 were selected for the study. To measure their livelihood security of the SHG tribal farm women, an index developed by (Eqbal, 2015) used with modifications. The index was based on 10 sub-indicators of livelihood security i.e. food security index, community empowerment index, community educational security index, gender equality index, economic efficiency index, ecological security index, community participation index, infrastructure security index, employment security index and sustainable farm diversification index. The overall extent of livelihood security was found as majority of the respondents in case of food security $(60.00 \%)$, community empowerment (87.50\%), community educational security $(82.50 \%)$, gender equality $(47.00 \%)$, economic efficiency $(58.00 \%)$, ecological security $(77.50 \%)$, community participation $(86.50 \%)$, infrastructure security $(74.00 \%)$, employment security $(71.00 \%)$, sustainable farm diversification $(69.50 \%)$, all these sub- indicators comes under medium level of livelihood security index. In case of Overall livelihood security index, 69.00 per cent was observed which comes under medium level of category.
\end{abstract}

\section{Introduction}

The Education Commission (1964-66) had recommended that a vigorous effort be made to establish specialized institutions to provide vocational education in agriculture and allied fields at the pre and post matriculate levels to cater the training needs of a large number of boys and girls coming from rural areas. The Commission, further, suggested that such institutions be named as 'Agricultural Polytechnics'. The recommendation of the
Commission was thoroughly discussed: during 1966-72 by the Ministry of Education, Ministry of Agriculture, Planning Commission, Indian Council of Agricultural Research (ICAR) and other allied institutions. Finally, the ICAR mooted the idea of establishing Krishi Vigyan Kendras (Agricultural Science Centres) as innovative institutions for imparting vocational training to the practicing farmers, school dropouts and field level extension functionaries. The first KVK, on a pilot basis, was established in 1974 
at Puducherry (Pondicherry) under the administrative control of the Tamil Nadu Agricultural University, Coimbatore.

Indian Council for Agricultural Research (ICAR) has established a large network of over 700 Krishi Vigyan Kendras (KVKs) across the country with an aim to conduct technology assessment, knowledge dissemination and provide critical input support for the farmers with a multidisciplinary approach. Initially KVK had conducted a survey in the selected villages from jurisdiction. The PRA and farmers interview method were adopted for collection of data on farming situations, gaps in adoption of technology, farming system, existing problems, etc. Primarily the natural resources like water, soil, vegetation and its related problems were studied. The farmers were categorized based on different enterprises like cultivation of particular crops, practicing dairy, poultry, etc, accordingly their existing practices are analyzed.

Considering all the existing practices and factors affecting the productivities, the gaps in adoption of recommended technologies were identified. According to farmers category based on different enterprises, farming situations and gaps in adoption, the critical inputs and critical skill oriented practice are analyzed for re-synthesized, assessment and refinement in case of proven technologies. Keeping this view, training \& demonstrations programme for practicing farmers, rural youth, front line demonstrations and on farm trials on latest technologies were included in the action plan of the KVK. The KVK have to work for the "reached to the unreached people" i.e. mainly for poor resources farmers like tribal's of the district.

The tribal population is an integral part of India's social framework and has the second largest concentration. Tribal population in
India is 104.3 million, which constitute $8.6 \%$ of tribal population (Census of India, 2011). There are about 449 tribes and sub tribes in different parts of India. The state of Madhya Pradesh, Maharashtra, Orisa, Gujrat, Rajsathan, Jharkhand, Chhattisgad, Andhra Pradesh, West Bengal and Karnataka are the states having larger number of scheduled tribes. These states accounts for $83.2 \%$ of the total schedule tribe population of the country. Remaining states including seven sisters of eastern states, Tamil Nadu, accounts for another $15.3 \%$ of the total scheduled tribal population.

Tribal's have traditionally living in about 15.00 percent of the country's geographical areas, mainly forests, hills, undulating inaccessible terrain in plateu areas and rich in natural resources. They have lived as isolated entities for centuries, largely untouched by the society around them. This seclusion has been responsible for the slower growth, dissimilar pattern of their socio economic, cultural development and inability to negotiate and cope with the consequences of their involuntary integration into mainsrean society and economy. Tribal forest economy is primarily a women`s economy, and it is women who are most directly affected by the corporate exploitation Tribal's live in farflung areas often outside the reach of modern means of information and communication technology. They are thus deprived of crucial information regarding development initiatives, employment programmes etc.

Government is plays crucial role for their development. Many schemes are implementing by the Government for the upliftment of tribal community. KVK, Palghar of Maharashtra state is established in 1977 for the improvement of standard of living of this primitive group of society. KVK Palghar has been implementing various entrepreneurship development activities among the tribal youth 
more particularly tribal women. These activities namely back yard poultry, value addition in finger millet, nursery, jasmine production, goat keeping, vermiculture production has emerged as an alternative sources of livelihood for small and marginal farmers. The income for these farmers, who were entirely dependent on agriculture, was very low because of dwindling natural resources and fragmented landholdings. To augment their income, 'Entrepreneurship development ' the model is suitable for small and marginal farmers has been successfully tried in the predominantly tribal pockets of Jawhar, Vikramgad, Dahanu, Talasari and Palghar talukas of the Palghar district in Maharashtra. The study role of KVK in strengthening livelihood security of SHG tribal women is necessary to measure scientifically; the study was planned with this specific objective.

\section{Materials and Methods}

The present study was conducted in purposively selected Palghar district of Maharashtra state which is tribal dominated district. Total two blocks were selected, each block five villages were selected randomly where KVK has given training to the SHG tribal farm women. Thus, a total 10 villages were selected and from each selected villages 20respondents were selected. Thus, total 200 were selected for the study. The data were collected with the help of structured interview schedule and prepared on the basis of specific objective of the study, in order to collect the required information.

Schedule was pretested in non-sampling area and adjusted necessary modifications as per their feedback. The collected data were scored, compiled, tabulated and subject to various appropriate statistical tools in order to draw significant results and reasonable conclusions.
Livelihood security was operationalized as an adequate access to income and other resources to meet their basic needs including food and nutrition, educational opportunity, employment security etc. To measure their livelihood security of the SHG tribal farm women, an index developed by (Eqbal 2015) used with modifications. The index was based on 10 sub-indicators of livelihood security i.e. food security index, community empowerment index, community educational security index, gender equality index, economic efficiency index, ecological security index, community participation index, infrastructure security index, employment security index and sustainable farm diversification index. It has been calculated by adopting the mathematical formula.

$\left(\mathrm{I}_{1 \mathrm{X}}+\mathrm{I}_{2 \mathrm{X}}+\mathrm{I}_{3 \mathrm{X}}+\ldots \ldots \ldots \mathrm{I}_{10 \mathrm{X}}\right)$
Livelihood security IndeX $=--------\mathrm{X} \mathrm{100}$
$\left(\mathrm{I}_{1 \mathrm{Y}}+\mathrm{I}_{2 \mathrm{Y}}+\mathrm{I}_{3 \mathrm{Y}}+\ldots \ldots \ldots \mathrm{I}_{10 \mathrm{Y}}\right)$

Where,

$I_{1 x}=$ Total score obtained by the $1^{\text {st }}$ component

$\mathrm{I}_{2 \mathrm{x}}=$ Total score obtained by $2^{\text {nd }}$ component

$\mathrm{I}_{10 \mathrm{x}}=$ Total score obtained by the $10^{\text {th }}$ component

$I_{1 Y}=$ Total maximum possible score for $1^{\text {st }}$ component by an individual

$I_{2 Y}=$ Total maximum possible score for $2^{\text {nd }}$ component by an individual

$\mathrm{I}_{10 \mathrm{Y}}=$ Total maximum possible score for $10^{\text {th }}$ component by an individual

\section{Results and Discussion}

In this study, livelihood security of the respondents was operationalized based on ten 
indicators. The level and distribution of respondents in each indicator of livelihood security in the study area have been presented under following table 1.

Table 1 reveals that, majority $(60.00 \%)$ of the respondents were having medium level of food security level of index while equally shared $(20.00 \%)$ low and high level of food security. This indicates that satisfactory level of food security observed due to adoption of entrepreneurial activities for their improvement.

Regarding community empowerment, it is observed that, majority $(87.50 \%)$ of the respondents were having medium community empowerment followed by high $(9.00 \%)$ and low $(3.50 \%)$ respectively. It's clearly indicates that due to SHGs member and adopted income generation activity for their empowerment. They could be helped each other for their empowerment.

It can be reveal from table, which large number $(82.50 \%)$ of respondents in the study area having medium level of educational security followed by those having low $(11.50 \%)$ and high (06.00\%) levels of education security index respectively. It could be happened due to the more awareness about importance of education among the tribal women; they sent their children to Ashram schools which are also increasing in number in that area.

Data pertaining to gender equality, the majority $(47.00 \%)$ of the respondents were having medium level of gender equality followed by high $(28.00 \%)$ and low $(25.00 \%)$ respectively. It they strongly believes that, women are equally important in society. Women plays crucial role in their improvement of standard of living through their entrepreneurial activities. They helps household activities as well as farming activities.
Table 1 reveals that the majority $(58.00 \%)$ of the respondents were medium level of economic efficiency security in study area, while high and low level of economic security were 21.50 per cent and 20.50 percent respectively.

More than $50 \%$ of the respondents were having medium level of economic efficiency which indicated that the SHG tribal women having fairly good economic condition by the adoption of entrepreneurial activities.

The majority $(77.50 \%)$ of the respondents had medium level of ecological security followed by low (14.00\%) and high (8.00\%) level of ecological security.

It could be inferred that ecology as a prime factor of livelihood security, it could be influencing the same as they are lived in forest and hilly areas.

Regarding community participation index of the respondents in study area, it was found that majority $(86.50 \%)$ were having medium level of community participation index whereas, 8.50 per cent and 5.00 per cent were found high and low level of community participation index. It could be felt socially secure due to the members of SHG.

Regarding availability and accessibility of the respondents towards various infrastructural security of the study area, it was found that near about one third $(74.00 \%)$ of the respondents found medium level of infrastructural security while 17.50 per cent and 8.50 per cent were found low and high level of infrastructure security. The results inferred that there is fairly good infrastructural facility in their locality. So there is need to improve the infrastructural facility like road, electricity, water etc. Hence, tribal women can run income generating activities for their livelihood security. 
Table.1 Distribution of respondents on the basis of indicators of livelihood security

\begin{tabular}{|c|c|c|c|c|}
\hline Sr. No. & Distribution of Livelihood Security indicators & Frequency & Percentage & Mean \\
\hline \multirow[t]{4}{*}{1} & Food security index & & & \\
\hline & Low (Below14) & 40 & 20.00 & \\
\hline & Medium (15 to 17$)$ & 120 & 60.00 & 15.54 \\
\hline & High (Above 18) & 40 & 20.00 & \\
\hline \multirow[t]{4}{*}{2} & Community empowerment & & & \\
\hline & Low (Below 16) & 07 & 03.50 & \\
\hline & Medium (17 to 20$)$ & 175 & 87.50 & 18.84 \\
\hline & High (Above 21) & 18 & 09.00 & \\
\hline \multirow[t]{4}{*}{3} & Community Educational security & & & \\
\hline & Low (Below 11) & 23 & 11.50 & \\
\hline & Medium (12 to 14$)$ & 165 & 82.50 & 12.93 \\
\hline & High (Above 15) & 12 & 06.00 & \\
\hline \multirow[t]{4}{*}{4} & Gender Equality & & & \\
\hline & Low (Below 17) & 50 & 25.00 & \\
\hline & Medium (18 to 19$)$ & 94 & 47.00 & 18.48 \\
\hline & High (Above 20) & 56 & 28.00 & \\
\hline \multirow[t]{4}{*}{5} & Economic efficiency & & & \\
\hline & Low (Below 21) & 43 & 21.50 & \\
\hline & Medium (22 to 24$)$ & 116 & 58.00 & 23.04 \\
\hline & High (Above 25) & 41 & 20.50 & \\
\hline \multirow[t]{4}{*}{6} & Ecological security & & & \\
\hline & Low (Below 18) & 28 & 14.00 & \\
\hline & Medium (19 to 22 ) & 155 & 77.50 & 20.42 \\
\hline & High (Above 23) & 17 & 08.50 & \\
\hline \multirow[t]{4}{*}{7} & Community participation & & & \\
\hline & Low (Below 14) & 10 & 05.00 & \\
\hline & Medium (15 to 19$)$ & 173 & 86.50 & 17.22 \\
\hline & High (Above 20) & 17 & 08.50 & \\
\hline \multirow[t]{4}{*}{8} & Infrastructure security & & & \\
\hline & Low (Below 10) & 35 & 17.50 & \\
\hline & Medium (11 to 14$)$ & 148 & 74.00 & 12.52 \\
\hline & High (Above 15) & 17 & 08.50 & \\
\hline \multirow[t]{4}{*}{9} & Employment security & & & \\
\hline & Low (Below 13) & 23 & 11.50 & \\
\hline & Medium (14 to 16$)$ & 142 & 71.00 & 15.19 \\
\hline & High (Above 17) & 35 & 17.50 & \\
\hline \multirow[t]{4}{*}{10} & Sustainable farm diversification & & & \\
\hline & Low (Below 13) & 10 & 05.00 & \\
\hline & Medium (14 to 16$)$ & 139 & 69.50 & 15.48 \\
\hline & High (Above 17) & 51 & 25.50 & \\
\hline \multirow[t]{4}{*}{11} & Overall Livelihood Security Index & & & \\
\hline & Low (Below 160) & 22 & 11.00 & \\
\hline & Medium (161 to 175 ) & 138 & 69.00 & 169.50 \\
\hline & High (Above 176) & 40 & 20.00 & \\
\hline
\end{tabular}


Table 1 reveals that majority $(71.00 \%)$ of the respondent were found medium level of employment security while 17.50 per cent and 11.50 per cent found high and low level of employment security index. It means SHG tribal women engaged in various entrepreneurial activities provided good employment security.

Regarding sustainable farm development security index showed that majority $(69.50 \%)$ of the respondents from study area having medium level of sustainable farm development while, 25.00 percent and 5.00 per cent respondent were observed high and low level of sustainable farm development index. It could be inferred that land is basic thing for tribal family, though the tribal women runs the entrepreneurial activities. Hence, they were having fairly good sustainable farm development security.

Table 1 showed that the distribution of the respondents based on their overall livelihood security into three categories viz., low, medium and high. The overall score for livelihood security of a respondent was calculated by taking into consideration of the scores from different indicators of livelihood security food security, community empowerment, community educational security, gender equality, economic efficiency, ecological security, community participation security, infrastructure development security, infrastructural security and sustainable farm development security. Each indicator of livelihood security was multiplied with the respective weightage to find out overall score for livelihood security index of the respondents from study area. It is evident from table 1, that majority $(69.00 \%)$ of the respondents had medium level of livelihood security whereas, 20.00 per cent and 11.00 per cent had observed high and low level of livelihood security respectively. It can be concluded from the result that majority of the respondents from study area had feeling secured with respect livelihood. Among all the ten indicators, economic efficiency and food security was contributing maximum towards the overall livelihood security while infrastructure security and community participation contributing less to the overall livelihood security.

KVK has plays major crucial role for the improvement of livelihood security of SHG tribal farm women of Palghar district through the implementation of various entrepreneurial activities like, poultry management, jasmine production, goat keeping and value addition in millet, which helped to improve their standard of living, food security, employment and educational opportunities as well as income security and community participation.

\section{References}

Bagri, P. Kumar (2014) 'A study on management pattern of sustainable livelihood diversification among small \& marginal farmers in Shahdol district (M.P.)', M.Sc. (Agri.) Thesis, Jawaharlal Nehru Krishi Vishwa Vidyalaya, Jabalpur, Madhya Pradesh, India.

Biradar, B. N. (2008) 'Impact of income generating activities on sustainable rural livelihoods of Kawad project beneficiaries.' M.Sc. (Agri.) Thesis, University of Agriculture Sciences, Dharwad, Karnataka.

Datta Jayasree (2013) 'Sustainability of Jhum cultivation as perceived by the tribal people of Tripura and their livelihood status'. M.Sc. (Agri.) Thesis, University of Agricultural Sciences, Bangalore, Karnataka.

Hari Ram Bam Barela (2018) Assessment of livelihood security of tribal farmers: A case study from tribal area of Madhya Pradesh, India. International journal of 
current Microbiology and Applied sciences, pp $1835-1841$.

Kiran, S. (2011) 'A Critical Study on Livelihoods of tribal farmers in Andhra Pradesh'. Ph.D. (Ag.) Thesis, The School of Agricultural Science Yashwantrao Chavan Maharashtra Open University Nashik Maharashtra,
India.

Patange, R. P. (2017) 'Socio-economic study of tribal households in Palghar district' (M.S.). M.Sc. (Agri.) Thesis, Dr. Balasaheb Sawant Konkan Krishi Vidyapeeth, Dapoli, Ratnagiri, Maharashtra.

\section{How to cite this article:}

Vilas Jadhav and Venkat Pirabu, J. 2019. Role of KVK in Strengthening of Livelihood Security of Self Help Group Tribal Farm Women in Palghar District, India. Int.J.Curr.Microbiol.App.Sci. 8(08): 1151-1157. doi: https://doi.org/10.20546/ijcmas.2019.808.135 